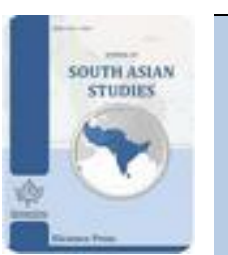

Available Online at EScience Press

Journal of South Asian Studies

ISSN: 2307-4000 (Online), 2308-7846 (Print)

https://esciencepress.net/journals/JSAS

\title{
Federalism Practice in Nepal Prospects and Upshots
}

\author{
${ }^{a}$ Keshav Kumar Acharya, ${ }^{b}$ Anil Chandrika \\ a German Development Cooperation, Nepal. \\ b Development Partner Cell, Ministry of Federal Affairs and General Administration, Nepal. \\ *Corresponding Author Email ID: keshavkacharya@outlook.com
}

\begin{abstract}
A B S T RA C T
This paper examines the core attributes and characteristics of federalism such as state restructuring, power-sharing, ensuring fundamental rights, and intergovernmental relationships. These are underpinned by constitutional provisions of 2015. Both primary and secondary information were used as a data sources. However, the constitution 2015 and citizens' responses were used as major sources of information. Seventy-two key informant interviews were administered purposely to triangulate the results. Findings indicate that the state was reformed into 7 provinces, and 753 local government units. However, much debate and discussions could not take place adequately on behalf of the state regarding the state restructuring process, nor had any established principles and criteria been used. As a result, there are many doubts have been emerged to implement federalism at the grassroots level. Although the government saying was that few indicators were designed to restructure the local governments, the political parties mainly Madheshi and identity-based sub-regional groups differed to the government decision. In addition, the constitution gives legislative, executive, and judiciary functions to all levels of governments, while capacity restraints, and lack of adequate legal procedures; federation have been extending its dominant role. Latterly, the inter-government relationship was adversely affected due for various reasons. For instance, firstly, imbalances of vertical and horizontal relationships; Secondly, provincial, and local governments' fiscal dependency on the federal government; and thirdly, power-seeking attitude of the bureaucracy. In the end, an applicable mechanism of service delivery and governance integrity is recommended for to effective federalization.
\end{abstract}

Keywords: Federalism, state restructuring, local governments, power sharing, Constitution, Nepal.

\section{INTRODUCTION}

'Federalism is a ruling system of governance, which distributes power and functions between national and sub-national government units that serve as a check and balance on each other, resolves the issues related to services of different level of governments in a collectively manner, and encourage for innovation in law and policy formulation (Kelemen 2003: 185). Zafarullah \& Huque (2012:283) considers "the intergovernmental relations, which is a key element of the federalism, in which a number of units come together to obtain various benefits". Thus, federalism in a way that "two broad levels of government with assigned powers and functions originating from a variety of factors and political bargains and displaying a tendency to persist through active response to the challenges of changing environment by a process of adaptation through creative modes of institutional as well as functional relationship" (Paleker, 2006: 309). Experiences (Inman \& Rubinfeld, 2020; Shah, 2007; Burgess, 2005) indicate that federalism is governed mainly in democratic nations including Brazil, South Arica, Canada, the U.S., Australia, India Argentina, and new democratic nation Iraq which promote the right of voice and participation in political life. This suggests federalism on the one hand is a governing system of governance wherein the local units experience a constitutional status and derive an inherent power to govern the state. On the other hand, federalism alone has not adequate capacity to resolve the issues triggered by the multiple actors and forces and run the new governance system (Rao, 2016).

The federalism in Nepal was considered as panacea of 
exclusion and marginalization as the Nepalese society is characterized by an ethnically diversified feudal system and complex power structure. Such structural constraints and political oppression have fertilized social exclusion, stimulated poverty, and social oppression, and created regional disparities, which is prolonged in Nepali society during the lichhivi period and became more chronic in panchayat period (Acharya, 2015; Suhrke, 2014). In Nepal, the core values of federalism are realized as primary model of governance to address the multi-ethnic, multi-lingual and multi-religious issues, which evolve in the society as exceptional debate after logical end of the comprehensive Peace Accord 2006 (Acharya, 2018). In line of the federalism, Nepal attempted to be a "Federal Republic" since Constitutional Act 1948 followed by interim constitution 1951 and amended constitution of Nepal 1962. Nevertheless, the democratic movements that took place in the world, including Nepal, in the 1990s, and the subsequent reform activities, created new opportunities to fulfill the hopes and aspirations of the people (Lamsal, 2013).

Despite that the conflict of internal interest of leading political parties that escalated insurgency war in view that 1996. The second Jana Andolan was held within the country to establish the federal republic system by abolishing autocratic monarchy. In 2006, a Comprehensive Peace Accord enacted to end the insurgency war and move the country towards path of federalism (Acharya, 2015). In 2007, an interim constitution of Nepal was promulgated that envisaged to restructure the country to resolve the issues of economic class, caste and ethnic, regional, and gender exclusion. Likewise, the interim constitution promised to institutionalize federal democratic republican system, fundamental rights of people, periodic election at all levels of governments, the provision of independent judicial system and good governance (GoN, 2007). In 2015, the government of Nepal promulgated federal constitution formally and ends the prolonged political transition.

Despite these actions to institutionalize the federalism process, numerous human right activists, Madhesh based political parties, and ethnic identity-based activists were not happy with some provisions of the constitution as they have been frequently arguing the new constitution and persistently challenging its clause and implementation process. On this perspective, the paper attempts to discuss the principal focus of the constitution of Nepal mainly on state restructuring, effective power sharing mechanism, ensuring fundamental rights to the citizen, and intergovernmental relationship, and assess the public responses on prospects and upshots of the of the federalization process.

\section{SCRUTINISING FEDERALISM: PRINCIPLES, PRACTICES, AND CONSEQUENCES}

Federalism is a governing system that considers decentralizing the political arrangement and economic viabilities, institute new institutions and institutional instruments, and create enabling environment to engage citizen in all levels of government based on democratic rights and responsive citizen (Burgess, 2005). It balances the separate political entities (federal, province and local), create trust between citizen and government within a more comprehensive political system, and encourage coordinating, collaborating and cooperating to all level of governments among to each other (Elazar, 1995). This instrumental process brings unity in diversity by harmonizing the opposing forces of centripetal and centrifugal entities. Consequently, many countries have adopted federal system to resolve the exclusion in terms of geographical accessibility, deeprooted social discrimination on caste and ethnic minorities, partiality on ethno-linguistic groups, and identity concern (Bulmer, 2017).

Some authors (Villiers, 2012; Burgess, 2005) contemplate that a well-functioning federal system is led by constitution and pluralist approach; however, federalism is understood as a political system that balances the distribution of power and responsibilities between different levels of government. Therefore, federalism creates a pattern of representation at the central and local levels, builds conducive environment for participation of all citizens including minorities, and prepare the foundation of good governance through the constitution.

According to Filippov \& Shvetsova (2013: 167) "a successful federalism requires all of its benefits: wellfunctioning democratic institutions, judicial system, integrated national political parties, and appropriate electoral incentives that created by democratic political competition". There are two major theoretical conceptions of federalism are considered in policy realm. First concept regards federalism to be a uniting force or bond which results to the joining of different 
nationalities into a single statehood through the sharing of governmental administrative offices among them. Second concept regards federalism as a way of joining different nations with visible dissimilarities to form a single statehood with a much-reduced objective (Amah, 2017). The most fundamental thing about federalism is a division of powers between levels of government and maintaining unity in spite of the people among the multilingual, multiethnic, multi-religious, and multiculture that have agreed to come together. Other characteristics of a federal arrangement are fiscal autonomy, rule of law, citizen led democracy, and demise inequality in population between regions (De Figueiredo \& Weingast, 2005).

The neoliberalism highlights the institutional restructurings, links institutions with market mechanism, and distributes power between national and sub-national level of governments so that federated government units can enjoy with granted power and functions (Harmes, 2007). Ostram (1991) illustrates that federalism is not just a form of government, but it is a method for solving problems, a way of life, which furnish the representational democracy under greater political participation and share province power with different level of governments-federal, province and local in which all levels have their own institutional setup that directly concern with people. Therefore, federalism is a prospect, movement and an agreement of nation building process. It anticipates a self-sustainable and public representatives' institutional mechanism, democratic institutions, shared political understanding, and an enabling environment for peoples' engagement in the service mechanism (Burgess, 2005). In this perspective, federalism creates harmonious "partnership" between different levels of government (Villiers, 2012; Shah, 2007). However, Riker (1964) believes that federalism is game of power politics, and rational choice in terms of political bargain.

In federal countries, federalism defines through two types of models. First, dual federalism distributes sovereignty between the federal and provincial governments in which provincial governments enjoy with allocated powers without obstacle of the federal government (Burgess, 2005). Australia, Canada, India, and Pakistan have been adopted dual federalism model to coordinate the lower level of governments (Galligan, 2006). In this system, the federal government is at the top, and the provinces and local governments are directed through legal procedures. Most importantly, this system does not advocate the local governments to have constitutional mandate role and responsibilities: they are simply extended arms of provincial governments. In this system, only provincial governments have significant authority of autonomy.

Second concerns with cooperative federalism that is a concept in which federation, provinces, and local governments work cooperatively and collectively to solve common problems (Burgess, 2005). Both national and sub-national governments each have primary responsibility granted by exclusive and concurrent powers of the constitution. For exclusive power, these units are autonomous whereas they need to build consensus for concurrent functions implementation. Germany and South Africa have been using cooperative federalism model that federal government promulgate the policies and laws, and the province and local governments implement as implementing actors(Shah, 2012).In cooperative federalism, all orders of government enjoy with legal autonomy. They coordinate each other both horizontally (Sharma, 2015). Under this cooperative federalism, both levels of government coordinate their actions to solve the problems expansion both government's power in concurrent policy areas, engage all levels of government in fiscal functions as equal partners (Galligan et al., 1991; Painter, 1996).

For some cases, society is classified by multilingual, multiethnic, multi-religious, and multi-culture dimension that fall under identity federalism, which address the demands for regional autonomy and settle down the ethnic tensions. For example, Canada, Switzerland, and many African countries have been adopting identity federalism (Erk, 2003), while efficiency federalism focuses on ethnic recognition, religious minorities, and linguistic or other cultural communities. It is realised that this model is more efficient in those nations where cultural homogeneity and large geographic area endured. Germany, and Argentina have executed this model to improve the democratic representation, resolve the issues of identity, give people greater opportunities to democratic control and distribute the resource and power to the lower level (Breen, 2018).

Thus, Shah (2006) articulates that the federalism either "coming together" or a "holding together" with administrative and geographic units for taking benefit of the greatness and smallness of nations. Watts (2002) 
further explained that federalism is a desire of smaller self-governing political units, like local government so that small units are more responsive to the individual citizen in terms of receiving services and to ensure that their aspirations to be recognized and accepted, freedom to express their identity particularly their linguistic, cultural ties, religious practices, historic traditions and social practices.

In federal nations (Jha, 2017), government focuses on building more legislative framework to enable greater degree of institutional mechanism and effective operational sing so that services can be delivered to all people. In Canada, the federal government has jurisdiction over entire the country and each provincial government has jurisdiction over particular portions of the population. Both levels of government derive their authority from the written constitution (Shah, 2006). In Philippines, federal constitution emphasis on the autonomy of local government units, as well as the recognition of the importance of information and communication technology in nation-building. It also provides political, social and economic rights, which entitle every citizen to decision making, access to food, healthcare, decent housing and livelihood (Moreno \& Colino, 2010). Unlike Canada and the United States, where federalism was realised for uniting states that had once been autonomous political entities, in Brazil federalism was a technique for dividing what had always been a unitary system of government (Rosenn, 2005). However, a new constitution was drafted in 1988 that granted broad array of exclusive powers to the federal government. These include the powers to maintain international relations; provide for defence; regulate currency, exchange rates, and mineral prospecting; and operate or regulate radio and television broadcasting, the post office, and the federal police (Souza, 2005).

Nevertheless, Dinch (2008) argues that unitary system was one of the devils we knew and replace it by federalism is also a devil we do not know. Anderson (2015) expresses that due to poverty, political instability, religious intolerance and poor governance in developing countries like India, Iraq and Nigeria, federalism has not achieved the expected results, nor has it been able to bridge the gap between different states and end communal and ethnic tensions. What is even more worrying is that in the past decades, there has been ample evidence that such issues have been sparking and badly strengthened. In Pakistan, federalism deviates from its basic principles because of its unnecessary focus on ethno-nationalism, conflicts, and separatism that results the marginalized and excluded groups have not given them equal opportunities or disenfranchisement from the state structure and their presence in the system of governance has been denied by the so-called elites (Khan, 2014).

Despite that federalism enables logical distribution of shared power among the different levels of governments in Australia that concludes complex and overlapping divisions of responsibilities, increases cooperation, and reduces duplication of effort. However, critical issues relating to the dynamics of intergovernmental relations and the impact of federalism on sectoral development are yet to be analyzed (Dredge \& Jenkins, 2003). Painter (1996) adds that federalism can be organise both positive and negative effects around three main themes: countervailing power, overlapping jurisdictions and multiple accountabilities.

In the case of Nepal, the country has formally abolished the unitary structure and adopted cooperative federalism system aiming with three tires of governments, clear division of legislative, executive and judicial functions, and legitimized institutions closed relationship with citizens. This mechanism envisages different tires of the governments and allows designing the integrated policies to address the needs and demands of the different tires of governments (Brand, 2006). However, some anomalies have been creating tension in institutionalizing federalism initiatives such as intergovernmental relations, devolution of sectoral functions, and connecting citizen in political decisionmaking process, create social protection and social safety nets (Acharya, 2018). The constitution has elaborated three principles such as cooperation, coexistence, and coordination, which create enabling environment for administrative, political, and fiscal federalism. This practice indicates that Nepalese federalism is a hybrid federalism that power including fiscal resources has been divided among the three level of governments. This perspective bestows unprecedented scale of autonomy of exclusive and concurrent functions to the federal, provinces, and local governments. However, Nepal's federalism is designed as a top-down process that has created chaotic relationship on Cooperation, coexistence and coordination among the level of governments. The study examines the key consideration of constitution to 
institutionalize the federalism and sought out the challenges that are currently facing.

\section{METHODOLOGY}

Both primary and secondary information were used for data source in this study. The secondary data sources mainly the Constitution 2015, Local Government Operation Act 2017, Intergovernmental Fiscal Transfer Act, 2017 and it's related several Acts and regulations were reviewed as major sources of information.

Similarly, seventy-two key informant interviews were completed purposively with different people of the federal, provincial and local governments for triangulation of the results. The fieldwork was done from February - September 2019 in which interview was conducted with 20 Mayor/Chair, 15 Deputy Mayor/Vice Chair, 10 Chief Administrative Officer, and 5 Dalit women members from local government units. Additionally, 2 chief ministers (Province 5, and 6), 2 ministers of Internal Affairs and Law (Province 1 and 3), 2 Principal Secretaries (Provinces 4 and 6) from provincial governments were selected. Next, 4 officials from Ministry of Federal Affairs and General Admiration as coordinating institution of LGs at the federal level, 2 representatives of local government associations, 2 representatives from development partners, 4 representatives from parliament led political parties (Communist Party of Nepal, Nepali Congress, Federal Socialist Forum Nepal, and Rastriya Janata Party Nepal) were included. During the data collection period, the author physically presented, and observed the operation of federalism, local governance and practice service delivery. These interviews were designed to gather the opinions and attitudes of participants on the effectiveness of federalism and power sharing mechanism under the federal mechanism. Open-ended and openstructured questionnaires were administered for the interviews. One-hour interviews were conducted with every interviewee, which was recorded electronically and transcribed later and presented according to the themes. At the end, the collected qualitative data was transcribed and coded according to four thematic issues and interpreted according to need. The result is discussed in section below.

\section{CONSTITUTIONAL ASSIGNMENTS INSTITUTIONALISE FEDERALISM}

This paper explores the conceptual framework for scrutinising federalism in Nepal. This section highlights the major provisions of constitution within the broader framework of the pluralist theory which emphasised on interdependency, diversity and the dynamic interaction of relatively independent layers of government. To streamline the focus of the paper, the following analytical framework was done.

\section{Reframing state structure}

Post comprehensive peace agreement 2006, state restructuring became a central political agenda of all political parties that was a basic entry point of federalism. In 2007, the interim constitution introduced the concept of 'federalism' first time and enforced state restructuring agenda formally in Nepali discourse. The constitution 2015 has further ensured Nepal is a multiethnic, multi-lingual, multi-religious, and economic class base society that fostered state to be restructured unanimously. On this process, people had great deal of expectation that the democratic government will adapt a well-known theory so that greater degree of pluralism, alliance, and citizen representativeness can be ensured. However, difficult geographical terrain, special interest of the politicians for their election constituencies, and identity feelings of the people not only confined the development opportunities, but also citizen faced acute problems of governance in the system, and amplified corruption at bureaucratic and political circle. To address the everlasting marginalization, federalism was an inevitable not merely the decentralizing of political power; it realized a powerful agenda of inclusion, which encompasses other institutional reforms, increases citizen engagement in the political decision making, and confirms ethnic proportional representation and cultural diversity. During the state restructuring process, three alternative ideas were recommended to the Local Level Restructuring Commission. These were ethnoregional and ethnic autonomous regions, regional capability, and regional politico-administrative divisions. To the state restructuring process, people's strong believe remained that the state restructuring process will contribute for logical conclusion of peace-building process, end troublesome exclusion, and scale up economic prosperity on the one hand. On the other hand, it could enforce to distribute unlimited central authority to the sub-national level.

In 2015, a new constitution was promulgated with consensus of more than 90 percent of people's representatives that imparted to restructure the state, machineries, and local government units for devolving of the power. The constitution declares Nepal is a federal 
republican country, which remains an independent, sovereign, secular, inclusive democratic, socialism oriented. To achieve these outcomes, the government of Nepal restructured the state into 7 provinces and more than 3000 local bodies into 753 local government units including Rural and Urban municipalities. As said local governments were restructured on the basis of few criteria such as size of population, extend of geography, principle of subsidiary, economies of scale, inclusivity, and representativeness, while there were no single criteria was used for provincial restructuring. In line with constitution, the state, functions, and functionaries were restructured and devolved to the provincial and local level as exclusive and concurrent forms. Consequently, the newly constituted provinces and local governments were enriched by several exclusive and concurrent powers. Although the current model of restructuring process has defined cooperative federalism, the wider participation of the political actors, technocratic engagement and peoples' referendum were absence in state restructuring process. Despite the association of the stakeholders during the restructuring process, the subsequent governments have been claiming on cooperation, coexistence and coordination of state restructuring process. In addition, the government brought discretion that all level of governments is equally responsible in protecting nation's independence, sovereignty, territorial integrity, autonomy, national interests, and inclusive representation and identity.

However, the Madhesh-based political parties, Dalit, ethnic and Tharu communities, who were not happy with current federalization process as they differed to the constitution and seven-province model. As they argued that the province restructuring process in Nepal was not based in any rational logic. They argued the provincial restructuring process was based on rulers' interest and their limit knowledge, which made the province nothing than a political pocket area. They believed that this process could not bring any tangible achievements merely changing government in each season. Although CPN-Maoist highlighted ethnicitybased federalism as they believed the caste system was a proponent for unequal power hierarchies over the societies. Later, Madhesh-based political parties, Dalit, ethnic and Tharu activists also claimed to demarcate the provinces according to their interests and boundaries drawn to make them dominant minorities. For example,
Madhesh-based political parties demanded a single province of Madhesh including 20 districts, which border to Indian boundary could ensure the right of the Madheshis, electoral constituency based on population only, amendment to citizenship laws, and proportional representation in every provincial institution

Despite the disagreements of Madhesh-based political parties, the local level election was completed across the country in 2017 that endowed opportunities to the large population, which were not a part of the local democracy in before. Through their votes, nearly 40 thousand people's representatives were elected at the local level to drive the local government units and practice the legislative judiciary and executive functions. Similarly, provincial and federal government elections were also completed to meet the constitutional deadline. In the beginning of 2018, both federal and provincial governments were formed that ended a prolonged and often-painful political transition. However, both politics and bureaucracy were fluid and lack capable to institutionalize federalism and maintain cooperation, coexistence and coordination at the lower level.

\section{Power sharing mechanism}

Powers including legislative, executive, and judiciary, which are enriched by the constitution to governments, federalization process enforces to divide between the national and sub-national governments. It is an instrumental to come up against market failures related to information asymmetries, and exclusively centralized decision-making. In Nepal, federalism considers solving the issues related to hard core poverty, sever exclusion, bad governance, and under development. Globally, federalism has been accredited not only as effective mechanisms to accommodate diversity or to overcome centralization, but also as powerful tools to strengthen democracy and public accountability for economic and social development. The constitution defines the structure of state and distribution of power among three different level of the governments. This provision has supported to achieve the stability of political order, social cohesion, and economic growth, while aimed to reinforce 'economic' and 'political' aspects of selfgoverning system massively. Current power sharing exercise ensured not only the governments remain more accountable to its citizens, or allocated resources as per real needs of the people, but also confirmed the multilevel governance actors to their political participation in legislative, executive and judiciary functions. Now, 
power sharing mechanism has been widely adapted among 753 local governments, 7 provincial governments, and a federal government.

The constitution further guaranteed that the power relations among the three level of governments are not hierarchically related, rather, their relationships have been based on the principles of co-existence, cooperation, and coordination'. Each type of government enjoyed certain exclusive powers that can be exercised independently, with concurrent powers of the federal, provinces, and municipalities are also allowed by constitution. Many best initiatives were appeared that such power sharing mechanism created interdependency mechanism of cooperation, competition, and shifting power from the centre to the local level. The federal, provincial and the local governments were able to build coordination to enact laws, make annual plan and budget, formulate policies and strategies, and implemented them regarding the subjects related to the fiscal power. However, federal government frequently instructed local governments through forwarding model laws in which Chief Administrative Officers were guided to approve from the council without any changes, recommending organogram model, revamping the district level offices in different names by neglecting and by-passing LGs, transferring inadequate revenue and budget to LGs in comparison to their functional mandates and expectations of the people, interfering to Integrated Property Tax system through fiscal Act. These types of actions created space for recentralization as federal bureaucrats were not ready to devolve the power and functions to the local governments; they remained dominant in the Nepali polity.

Despite the practices, the constitution has clearly indicated that each level government has responsibility to protect Nepal's sovereignty, autonomy, territorial integrity, and national interests, upholding the rule of law, while the separation of powers, plurality, and inclusive representation are major archetype of the constitution. Additionally, powers relating any subject that is not mentioned in the list of powers of the federation, province or the local level shall rest with the federation as residual powers. Further, foreign policy, national security, corruption control, regulation of I/NGOs, effective operation of National Investigation Department, the Department of Revenue Investigation, and the Department of Money Laundering Investigation are also a residual power of the federal government. To institutionalize the federalism, the federation has key responsibility to prepare basic laws, policies included in the list of concurrent/shared power, which were also be implemented in both provinces and local level. However, division of power equally in every society was one of the key challenges for federalization process. The basic reason was that the current federalization practices have put the federal government at the centre, while provincial and local governments are in peripheral as federal government controlled on more public revenue and expenditure and local and provincial governments were less authorized to levy the tax in various sources. This type of vertical power-sharing structure created ambiguities to implement the concurrent power of the constitution.

\section{Praxis Citizen Rights}

The fundamental rights and directive principles are containing to maintain the socio-economic equilibrium in the society. The constitutional purpose of these contents was to achieve the outcome of public welfare. It has reciprocal duties of both the state and the citizens towards others. These notions have empowered the citizens by guarantying the right to live with self-respect and dignity of people and many others. In Nepal, the government first time has ensured 31 fundamental rights of the people under the constitution 2015. For example, fundamental human rights such as right to freedom, right to equality, right to communication, right to justice, right against untouchability and discrimination, right to information, right to clean environment, right to education, right to health, food and shelter, to social security are the most prominent fundamental rights. These rights enforced the citizens to be faithful to their nation, trustworthy to their nationality, put their belief on sovereignty of state and integrity of the country, should abide by the law and constitution of the country. Apart from this, the constitution has address to those vital issues in a considerable extent. First, the constitution has made a sincere commitment to build a non-partisan and egalitarian society based on populism approach of proportional inclusion and meaningful participation in order to mainstream excluded, lack accessible and voiceless communities. Second, the three levels of government, the federal, state and local levels have been created based on plurality, and inclusive representation and identity. Third, it gives equal rights to marginalised 
communities, including Dalits to participate in all state agencies and state related decision-making processes on the basis of the principle of proportional inclusion. This will not only develop social cohesiveness and social capital but also reinforce the social and economic transformation of the marginalized community. Last but not the least, because of the principle of inclusion, it ensures that the various marginalized classes and Dalit communities have the same status as other classes in political participation, including employment provided by the state structure.

Notwithstanding all this, the constitution could not acquire unanimous acceptability. The Madheshi, ethnic, Tharu and Dalit communities account one-third population of the countries are claiming proportional representation in political and economic sectors as state bestow very little to them. As they were agitating on proportional representation, inclusion, citizenship and demarcation of the state territories, they claimed that four million Madhesis were without citizenship, although 26, 15, 615 citizenship certificates distributed after 2007. Similarly, differences were made that the current 7 provincial structure should be redrawing as Jhapa, Morang and Sunsari in the east, and Kailali and Kanchanpur in the west should be included in Madhesh province. Also, the issue of the Hindi languages which would serve as the official and working languages of the provinces. Nevertheless, federal and provincial governments have taken significant steps to conclude these issues.

In the face of constitution, it seems to be overburdened with a comprehensive catalogue of fundamental rights. Prior the interim Constitution 2007 provided merely for 21 fundamental rights, while the current constitution has guaranteed 31 fundamental rights and even issued a special list of them. Similarly, all citizens are interpreted as entitled to these fundamental rights. Therefore, the new constitution envisions a liberal democracy and establishes international human rights law as the basis for establishing the main interests of the people, such as social, political, economic and cultural rights.

\section{Institute intergovernmental relationships}

Intergovernmental relation is an indispensable process of the federalism, which build connections and interactions in power relationships and service functions among the governmental units of all types and levels. The intergovernmental relations include broad range of intergovernmental systems such as institutional and fiscal frameworks; capacity development of government actors; and support the frontlines for service delivery. The interim constitution 2007 commenced first time about state restructuring and created space to establish different levels of governments (federal, province and local) with high degree of autonomy within the federalism framework. To promote the interrelations among federation, province and local level, the Article from 231 to 236 of the constitution focuses on cooperation, coexistence and coordination principle, which, emphasis on fiscal and administrative processes by which these governments share revenues through inter fiscal transfer mechanism. According to the constitution, six major notions are highlighted to augment the intergovernmental relations. These are legislative interrelations between federation and provinces; inter-province council; coordination between federation, province and local level; commence inter-province trade; formal and informal processes of resource mobilization and institutional arrangements; promote strategic partnerships; and enlarge bilateral and multilateral cooperation within and between the three level of governments. The Article - 231 highlights that federation shall support the provinces to promulgate the legislations to build intergovernmental relations between federation and provinces. Also, federation should facilitate the provinces, if one or more provinces request federation to support them for preparing necessary laws to expedite exclusive rights illustrated on the schedule six ${ }^{\text {th }}$. Similarly, the Article 232 explains the intergovernmental relations of the federal, the provinces and the local level in equal status on the basis of the principles of co-operation, coexistence and co-ordination without subordinating or controlling each other. But the laws in this way should not contradict each other.

However, federation shall direct to provinces on matters of national importance and on matters provinces should follow such directions. If any undue acts are carried out in any province with intent to harm or seriously impairment Nepal's sovereignty, national integrity, regional brotherhood, sense of nationality or independence, the federation can warn such province, suspend or dissolve the provincial government for a period not exceeding six months. Concurrently, the federation can direct or assist to the local governments directly or through the provincial government under the 
constitution and the federal law. It is the duty of the local governments to abide by such directives. Also, Article 233 highlights about the relations between provinces that one province shall provide capability in the enactment of legal frameworks or judicial support or executive decisions or orders of next province.

Equally, a province should provide equal security, treatment and facility to residents of another province, if they settle in anther province.

Despite these interrelationship apparatuses, the constitution has provisioned number of institutional mechanisms to accelerate the intergovernmental relations. First, inter-province council mechanism has been provisioned under chairpersonship of the Prime Minister to settle political disputes arising between the federation and a province and between provinces. Second, the inter-province trade mechanism has been envisioned to avoid any kind of obstruction to freight vehicles or other purposes and service delivery objectives by a province or local level to another province or local level.

Third, the government promulgated Inter-Governmental Fiscal Management Act in 2017 as key fiscal governance Act. This act reinforces revenue administration system through revenue management, grant allocation, loan borrowing, budget distribution and expenditure, and public finance management at the federation, the province and the local level. Finally, it corrects the fiscal imbalances and reduce the disparities in local service delivery among the sub-national territories. Similarly, the Government of Nepal has approved the unbundling list of the exclusive and concurrent powers of the federation, province, and local level under Schedule-5, Schedule- 6, Schedule-7, Schedule-8, and Schedule-9.

However, numerous differences were emerged against inter-government relations. First, the variance remained to vertical and horizontal relationships among the governments. As constitution provisions that federation can direct to province and province can direct to local governments. However, local governments are always relied on federal government due to various reasons. First, the power and functions which distribute arbitrary to the local governments does not match with capabilities. Second, there were imbalances between functional authority and budgetary authority at the province and local level. Third is high fiscal dependency on the federal government. And finally, bureaucracy which is known as engine of federalism was highly corrupted and dominant at the local level in the past several years. These dynamics were adversely affected the quality of autonomy and institutionalizing intergovernment relations. However, this system is an outcome of cooperative systems, where the powers and responsibilities of all levels of government were overlapped or interlocked. Thus, effective communication, and mutual trust are dispensable to develop mechanisms and forums for formal coordination.

\section{DISCUSSIONS}

\section{Public access to service delivery}

In developing countries, state services are delivered by closed institutions as these institutions are commonly considered conventional (Acharya, 2016; Faguet, Fox, \& Poeschl, 2014). In this system, government is on the top, and bureaucrats and politicians are answerable for the performance of service mechanism, which favours the political and bureaucratic elites to maintain the hierarchic control whose power came from "underneath" (Mccourt, 2012). In the global context, many antitheses have been come out to criticize the conventional top-down approach. Major reasons were inability to deliver the goods and services to doorstep of the people, less competitive in achieving economic growth, over-bureaucracy and a rent seeking attitude (Paudel, 2011). To overcome the situation, federalism is carefully deliberated contingent instrumental that compound mode of governments (federal, provincial, and local governments) in a single political system. Its distinctive feature is exemplified by the United States of America under the Constitution of 1787, which maintain the relationships and divide the powers between two levels of government in equal status (Beer, 1978). In Nepal, public service delivery was substandard in the past as bureaucracy believed in hierarchy, and politicians were only accessible to elite power holders that contributed to cripple down the public services and red-tapismrampant (Acharya, 2015). Since 2007, federalism has been entrusted on the grounds that allow people to choose more democratic government to localized issues, work as more autonomous entity, and it maintains checks and balances of each government to institute better governance. As result, public trust is amplified to entrusted federalism in establishing political stability, reinforcing economic factors to scale up economic growth, creating enabling environment to mobilize internal resources and improving delivery of 
services.

In 2007, Nepal formulated interim constitution that abolished the monarchical system and prescribed federal democratic system, which is further instituted by the constitution 2015 under polycentric governance approach. This constitution not only amplifies the space to restructure the federal, provincial, and local governments and provides multi power and functions related to exclusive and concurrent, but also introduces measures for greater inclusion of women and Dalits among the marginalized communities within state mechanism (Acharya, 2018). To the federal government, it can use 35 exclusive powers and functions related to national importance, while provincial governments can exercise 21 exclusive powers autonomously related to provincial concerns. Following the constitution provisions, 21 exclusive powers are allocated for local level (GoN, 2015). This process of due course has been accompanying to institutionalize the federalism in Nepal. Further, Local Government Operation Act 2074 (B.S.) devolves the power and functions to the lower levels of local governments such as wards, and settlements as closest units of the grassroots people. These significant steps of the legislative frameworks have not only ensured the citizens to have access of the services at the doorsteps of the people, but also promote the social accountability.

Despite such constitutional provision, the capacity, knowledge, and law enforcement mechanism at all level governments ponder very weak. The federal government is still unable to resolve the employee adjustment at all levels of the governments. Similarly, the prolonged process of the employee adjustment and disputes between Civil Service Act based staff and local government staff has been created obstacle to implement the federalization process. The reasons are the allegation of civil service staff was that the local government employees are passive service providers, and they were unsuccessful to facilitate the federalism and institute local governance system.

At the province, the constraints related to institutional mechanism, law instruments, technical and financial resources, and supportive political environment were minimal. Next, the status of local governments is ambiguous with regard to the autonomy from the authority of the federal and provincial governments within whose power and functions they fall. In line such reality, Nepal still faces to reach the basic services at the doorstep of the people. This poor state of service delivery is due to captured power mechanism by super leaders of the majority based political parties, weak policy formulation, deficiency of transparency and accountability on financing and regulation; poor match between financial allocation and local preferences, and the service centers of the local governments were remotely located that coerced ordinary citizens facing hassles to access the core services(Acharya, 2016). This indicates bigger the size of the local government, the lesser the possibility of accessing services easily at the local level (Acharya, 2018).

\section{Integrity of governance}

The constitution 2015 defines Nepal as multi-ethnic, multi-lingual, multi-cultural and diverse geographical country whereby society is divided by the religions, cultures and castes that need to eliminate and build an egalitarian society based on the principles of proportional inclusion and participation, and social justice (GoN, 2015).

To achieve the federal objective, the Constitution sets out some key principles. First, the state structure of Nepal will be managed in three tiers, federal, provincial and local level. Thereafter, state power, rights and responsibilities will be exercised under the three main structures of government in accordance with this Constitution. Secondly, the power of each level of the structure has been set out in the given schedules and shall be exercised in accordance with this Constitution and the federal law (Adhikari, 2015). Thirdly, the Constitution also sets out concurrent/shared power of the federation and the province, and federation province and the local level (Dahal, 2017). Fourth, if such rights or responsibilities are not included or mentioned in the list of exclusive or concurrent rights of the federal, province or local level, it will remain as a residual power of the federation. The province and local levels should cooperate the federal government to exercise this right. Fifth, the Constitution also lays down norms for use of fiscal power and distribution of sources of revenue. Finally, in terms of legislation, the federal government makes laws, rules, policies and norms in the list of concurrent/shared power, in matters of national importance, in relation to economic policy and in the areas of financial rights, which are equally applicable at the provincial and local levels. However, the provinces and local levels can implement it within their jurisdiction by simplifying rather than deviating from 
the issues prepared by the union (Adhikari, 2015). In addition, the state restructuring process was an immediate result of the constitution promulgation that established not only tires of the government: federal, provincial and local governments, however also ascertained new governing systems by means of implementing a competitive multiparty democratic governance with constitutional sovereignty, periodic elections, rule of law, separation of powers in addition to check and balance, and an impartial judiciary mechanism (Acharya, 2018).The constitution confirms Nepal is still following to parliamentary system on the federal and provincial levels, which defines the structure of governance will be a multi-party, competitive, federal democratic republican parliamentary system based on plurality. The Prime minister is elected via the legislative parliament based on a majority is headed to government, while president is head of the state. In terms of judiciary, the Supreme Court considers overcoming the constitutional troubles. Apart from this, constitution provisions high courts in each province, district court at the district level, and judicial committee in each local government units (GoN, 2015).

In terms of the electoral system, a mixed system has been adopted at the federal level, it is a bi-cameral parliamentary form of government with a president elected through the legislative-parliament and the federal assembly, as well as the provincial level legislative units (Dahal, 2017). The House of Representatives in the federal parliament will consist of 275 members in which 165 members are elected from single-seat constituencies and 110 from a proportional party list. Similarly, the federal assembly consists of 59 members. In the provinces, the legislature will be unicameral. The Chief Minister of the state has been elected by the provincial legislature whereas the head of the province will be appointed by the President (GoN, 2015). In order to effective implementation of the governance, the constitution has provisioned constitutional commissions (National Human Rights Commission, Election Commission, Women Commission, Dalit Commission, Janajati Commission, Madhesi Commission, Tharu Commission and Muslim Commission). Additionally, a significant initiative of the Constitution is increasing women's' participation in state structures as they're provisioned one-third of seats within the Federal Parliament, likewise the provincial assemblies. It also entails that the positions of either
President or Vice-President of the country and Speaker or Deputy Speaker be filled by a woman (GoN, 2015). However, women have been ensured 33 percent of seats in the parliament, majorities in deputy positions. This indicates women are still facing various types of discrimination and realises them as better deputies. At the local level, women are guaranteed 40 percent representation. The recent elections confirmed 41 percent participation of women in representative bodies that indicate substantial achievement. However, public sector management isn't become independent of politics-political influences and social group preferences pervade every system, every relationship and each transaction.

The Madhesh based political parties and some ethnic or Janajati groups are demanding a major amendment to the constitution to make the federal structure more meaningful and more autonomous. The task ahead in implement thing the new constitution looks daunting. First, ushering the country towards a new era of economic development through political stability. Second, ensuring inclusivity in all aspects of governance. Third, managing identity politics. Fourth, decentralizing power and addressing the issues of transitional justice. In line to the above issues, the report of the Office of the Auditor General Nepal indicates that most of the local governments have not completed the public financing audit since past years. Similarly, the projects, which were done by the users' committees were not publicised the work progress, project cost, expenditure, project completion status, involved members. Recently, Office of the Auditor General has completed the public financing audit of 43 districts in which the local governments of 28 districts found chaotic and financial management looked mismatch. For example, the local governments in Rupandehi district found NRs. 40 million audit arrears followed by NRS 155.5 billon in Parsha district, and 4.5 million in Rolpa district (GoN, 2017). The main reasons to remain the large volume audit arrear were delay settlement of the advance, release the money without plan and projects, and uncontrolled expenditure in administrative and regulative works.

An example of Ethiopia shows the introduction of ethnic federalism has allowed a better recognition of linguistic and cultural rights in Ethiopia, nevertheless it was failed to bring political stability and peace rather increased local ethnic conflicts (Bélair, 2016). However, federalism process deliberately devotes to devolve more power to 
the provinces and local level with responsibility and accountability, which gives more voice, more participation and more initiatives of the people. It is not a division of the country on administrative lines nor is it a division of resources, while it is people-centric and focuses democracy values and functions.

\section{CONCLUSIONS}

Federalism is not merely a shared rule system that enforces the governing bodies to execute the power and functions according to constitutional framework, but also it makes both public institutions and elected people's representatives more accountable and responsive. This paper attempted to analyze the key attributes and rationale behind the federalism aspects of the constitution of Nepal, whereby, deconstructing the constitution through the theoretical attributes of federalism, like state restructuring, power-sharing, scope of fundamental rights and directive principles, and intergovernmental relationship. From the analysis, it is evidently clearing that the constitution has comprised the idea of the integrated cooperative federalism, without explicitly addressing the core attributes of federalism. The constitution has adequately spelled out the role of each level of governments. However, the role of sub-national governments has found little mainly concerning formulating policies, and Acts, and sharing revenue. On these aspects, the province and local governments are significantly relied on the federal government. Despite the constitutional power on legislative, executive, and judiciary at the local level, the role of local governments is not beyond the regulative institution of federal ministries in managing and implementing of the national programme on conditional grant. In addition, the local governments are facing upheavals in capacity lack, expenditure management, unnecessarily increment of development partners, contradiction on duties and work responsibilities, adhoc adjustment process of the employs and fiduciary risk in expenditure management.

However, federalism is considered as panacea to distribute the power and functions among the governments. Success of the federalism is subject to the actions, and results of the political leadership, state bureaucracy and citizens' response. There are four critical ways in which the federal concept can be operated. First, the actions, and results of the federal concept nurtures diversity within unity. It resolves the greater degree of social, economic, and political differences. Secondly, the federal idea encourages inventiveness, and innovation in meeting the needs of the people. By providing several sources of political strength and inventiveness, a federal system invites intensive leadership, on all levels to work towards genuine solutions to the problems of a diverse and complex society. Finally, the federal idea is characterized by a balance which prevents excesses and invites the full, free play of innovation and initiative. This balance is essentially achieved by the division of powers between the national and state governments, the separation of legislative, executive, and judicial authority, the absence of monolithic national parties.

\section{REFERENCE}

Acharya, K.K., (2018). The capacity of local governments in Nepal: from government to governance and governability? Asia Pacific Journal of Public Administration. 40(3), 186-197.

Acharya, K. K. (2016). Determinants of Community Governance for Effective Basic Service Delivery in Nepal. Dhaulagiri Journal of Sociology and Anthropology. Vol. 10, 143-178.

Acharya, K. K. (2015). Community governance and peacebuilding in Nepal. Rural Society. 24(1), 65-84.

Adhikari, B., (2015). Salient Features of the Constitution of Nepal 2015 (2072). Nepalese Constitutional Law, Governance and Public policy Issue. Retrieved at http:// https://bipinadhikari.com.np/quickcomments/salient-features-of-the-constitution-ofnepal-2015-2072/on 17th March 2020.

Amah, E., (2017) Federalism, Nigerian Federal Constitution and the Practice of Federalism: An Appraisal. Beijing Law Review, 8, 287-310.

Anderson, L., (2015). Ethno-federalism and the Management of Ethnic Conflict: Assessing the Alternatives, Publius: The Journal of Federalism, 46(1), 1-24.

Beer, S. H. (1978). Federalism, Nationalism, and Democracy in America. American Political Science Review, 72(1), 9-21.

Bélair, J., (2016). Ethnic federalism and conflicts in Ethiopia, Canadian Journal of African Studies, 50(2), 295-301.

Belbase, N. \& Thapa, L.B., (2007). Environmental justice and rural communities, Nepal. In: Moore, P., Pastakia, F. (Eds.), Environmental Justice and Rural Communities, Studies from India and Nepal. IUCN Bangkok, Thailand and Gland, Switzerland. 
Bhattacharyya, H., (2005). Federalism and Regionalism in India Institutional Strategies and Political Accommodation of Identity, Heidelberg Papers in South Asian and Comparative Politics, Working Paper No 27, University of Heidelberg.

Breen, M.G., (2018). Nepal, federalism and participatory constitution making deliberative democracy and divided societies, Asian Journal of Political Science, 1-21.

Bulmer, E., (2017). Federalism, Stockholm, International Institute for Democracy and Electoral Assistance.

Burgess, M., (2005). Comparative Federalism, New York: Routledge.

Chen, P. (1999). Federalism and Rights: A Neglected Relationship, Law Review, 40(Summer), 845-850.

Cox, R.H., (2001). The Social Construction of an Imperative: Why Welfare Reform Happened in Denmark and the Netherlands but Not in Germany, World Politics 53(3): 63-98.

Dahal, K.M., (2017). The Constitution of Nepal: On the Touchstone of Constitutionalism and Good Governance, Journal of Political Science, Vol.17: 3651.

De Figueiredo, R. J. P. Jr., \&Weingast, B. R., (2005). Selfenforcing federalism, The Journal of Law, Economics, \& Organisation, 21(1), 103-135.

Denich, B., (1994). Dismembering Yugoslavia: Nationalist Ideologies and the Symbolic Revival of Genocide. American Ethnologist, 21(2), pp. 367-390.

Dinch, V.D., (2008). Structures of Governance: "Fixing" International Law with Lessons from Constitutional and Corporate Governance, New York University Journal of Law and Liberty, 3: 423-447.

Dredge, D. \& Jenkins, J., (2003). Federal-State Relations and Tourism Public Policy, New South Wales, Australia. Current Issues in Tourism. 6(5), 415-443.

Elazar, D.J., (1995). Federalism: An Overview, Pretoria, Human Sciences Research Council.

Elazar, D. J. (1994). Introduction, Federal Systems of the World: A Handbook of Federal, Confederal and Autonomy Arrangements, New York: Stockton Press.

Erk, J., (2003). Swiss Federalism and Congruence, Nationalism and Ethnic Politics, 9(2), 50-74.

Faguet, J., Fox, A. M. \&Poeschl, C., (2014). Does decentralisation strengthen or weaken the state? Authority and social learning in a supple state.
London, London School of Economics and Political Science.

Filippov, M. and Shvetsova, O., (2013). Federalism, Democracy and Decentralisation, In (Eds.) A. Benz and J. Broschek, Federal Dynamics: Continuity, Change, and the Varieties of Federalism Oxford, Oxford University Press.

Finer, H., (1961). Theory and Practice of Modern Government, Delhi, Surjeet Publishers.

Garran, R., (1929). Report of the Royal Commission on Australian Constitution, Canberra, Australia Royal Commission.

GoN, (2017). The Auditor General's Fifty Fourth Annual Report 2017, Kathmandu, The Office of the Auditor General.

GoN, (2015). The Constitution of Nepal. Kathmandu. Nepal Law Commission.

GoN, (2007). The Interim Constitution of Nepal. Kathmandu 2063. Nepal Law Commission.

Harmes, A., (2007). The Political Economy of Open Federalism. Canadian Journal of Political Science, 40(2), 417-437.

Heywood, A., (2013). Politics. United Kingdom: Palgrave Macmillan.

Heydarian, R., (2018). Does Federalism Make Sense for The Philippines? Forbes, Retrieved: https://www.forbes.com/sites/richardheydarian/ 2018/07/19/does-federalism-make-sense-for-thephilippines/\#4c2c1cfa77cf.

Galligan, B., Hughes, O. and Walsh, C. (1991). Intergovernmental Relations in Australia. Sydney: Allen and Unwin.

Galligan, B., (2006). Comparative Federalism, In:S.A. Binder, R. A. W. Rhodes, \& B. A. Rockman (Eds.),The Oxford Handbook of Political Institutions (pp. 261280). Oxford University Press.

George, V., (2018). Social Security: Beveridge and After, London, Routledge.

Jha, K. K. (2017). Federalism History and Challenges in Nepal, Madhesi Youth: Grassroots Voice for Marginalised Groups in Nepal, Accessed at http://www.madhesiyouth.com/analysis/federalis m-history-challenges-nepal/.

Kelemen R. D., (2003). The Structure and Dynamics of EU Federalism. Comparative Political Studies, 36(1-2): 184-208.

Khan, M.S., (2014). Ethnic federalism in Pakistan: federal design, construction of ethno-linguistic identity \& 
group conflict. Harvard Journal on Racial and Ethnic Justice, 30, 77-129.

Lamsal, A.K., (2013). Mass Revolution and End of the Cultural Institution in Nepal. Researcher, I(II). 1122.

Ndzendze, B., (2018). Traditional Authorities and Customary Law in a Democratic, Constitutional State. Law and Politics, 76, 6-33.

Mccourt, W. (2012). Can Top-down and Bottom-up be reconciled? Electoral Competition and Service Delivery in Malaysia. World Development, 40(11), 2329-2341.

Nobre, A., (1990). The Political Structure of the Federal Brazilian Republic Under the Constitution of 1988, Miami. University of Miami Inter-American Law Review.

Ostrom, V. (1991) American Federalism: Constituting a Self-Governing Society, San Francisco: ICS.

Painter, M. (1996). The Council of Australian Governments and Intergovernmental Relations: A case study of co-operative federalism. Publius. 26 (2), 101- 121.

Paleker, S. A., (2006). Federalism: a conceptual analysis, The Indian Journal of Political Science67(2), 303310.

Paudel, L. K. (2011). Governance of agriculture service delivery in Nepal: status, issues, and challenges. Nepalese Journal of Public Policy Governance, 29, 69-87.

Rao, G. M. \& Singh, N., (2006): The political economy of India's fiscal federal system and its reform, Working Paper, No. 06-10, Santa Cruz, University of California and Santa Cruz Institute for International Economics.

Riker, W. H. (1964). Federalism: Origin, Operation, Significance. Boston, Little Brown.

Rosenn, K.S. (2005). Federalism in Brazil. Miami, University of Miami Law School.

Posner, P., (2007). Politics of Coercive Federalism in the Bush Era. The Journal of Federalism, 37(3), 390412.

Shah, A., (2012). Executive Federalism: Working Behind Closed Doors to Make a Dysfunctional System of Multi-Order Governance Work, Conference: International Seminar on Fiscal Federalism. Turin.
University of Turin, Italy. July 2012.

Shah, A., (2007). Introduction: Principles of Fiscal Federalism. In Shah, A., Kincaid, J. (Eds.), The Practice of Fiscal Federalism: Comparative Perspectives (pp. 3-

42). McGill-Queen's University Press.

Shah, A. (2006). Fiscal Decentralisation and Macroeconomic Management, International Tax and Public Finance, 13(4), 437-62.

Sharma, C.K., (2015). Reimagining Federalism in India: Exploring the Frontiers of Collaborative Federal Architecture. Asia-Pacific Social Science Review, 15 (1), 1-25.

Singh, M.P. \& Verney, D. V., (2003). Challenges to India's Centralised Parliamentary Federalism, Publius: The Journal of Federalism, 33 (4), 1-20.

Souza, C., (2005). "Federal Republic of Brazil" in Kincaid, John and Tarr, Alan (eds.) Constitutional origins structure and change in Federal Democracies. Mc Gill Queen's University Press.

Taft, W. H. IV, (1977). Recent Developments in Social Welfare Law and the Doctrine of Separation of Powers, Indiana Law Journal, 52(2), 345-366.

Tillin, L., \& Pereira, A. (2017). Federalism, multi-level elections and social policy in Brazil and India, Commonwealth \& Comparative Politics, 55(3), 328352.

Watts, R.L. (1999) Comparing Federal Systems. Montreal: McGill-McQueens University Press.

Wibbels, E., (2005). Federalism and the Market: Intergovernmental Conflict and Economic Reform in the Developing World, New York, Cambridge University Press.

Zafarullah, H. \&Huque, A. S., (2012). Managing Development in a Globalized World: Concepts, Processes, Institutions, Boca Raton, Taylor \& Francis, CRC Press.

Uddin, K.M.K., Quaosar, G.A.A. and Nandi, D.C. (2013). Factors affecting the fluctuation in exchange rate of the Bangladesh: A co-integration approach. International Journal of Social Sciences, 18(1), 1-12.

Wanaguru, S. (2015). From Where Does It Come? An Analysis of Currency Market Volatility in Sri Lanka. Staff Studies, 42(1), 75-97. 
Publisher's note: EScience Press remains neutral with regard to jurisdictional claims in published maps and institutional affiliations. (⿶) use, sharing, adaptation, distribution and reproduction in any medium or format, as long as you give appropriate credit to the original author(s) and the source, provide a link to the Creative Commons license and indicate if changes were made. The images or other third-party material in this article are included in the article's Creative Commons license, unless indicated otherwise in a credit line to the material. If material is not included in the article's Creative Commons license and your intended use is not permitted by statutory regulation or exceeds the permitted use, you will need to obtain permission directly from the copyright holder. To view a copy of this license, visit http://creativecommons.org/licenses/by/4.0/.

(C) The Author(s) 2021. 